\title{
COMPUTATIONAL ASSESSMENT OF THE PHARMACOKINETICS AND TOXICITY OF THE INTENSIVE SWEETENERS
}

\author{
DENISA IOANA VOICULESCU, VASILE OSTAFE, ADRIANA ISVORAN*
}

\author{
Department of Biology-Chemistry and Advanced Environmental Research Laboratories, Faculty of Chemistry, Biology, \\ Geography, West University of Timişoara, Romania
}

*corresponding author: adriana.isvoran@e-uvt.ro

Manuscript received: January 2021

\begin{abstract}
The present study focuses on predicting the pharmacokinetics and toxicological endpoints of the widely used intensive sweeteners for preventing and management of diabetes: acesulfame K, advantame, aspartame, cyclamates, glycyrrhizin, neohesperidin dihydrochalcone, neotame, saccharin, steviol, sucralose, and tagatose. Predictions obtained using several computational tools were generally in good agreement each other and with few known data concerning the effects of these compounds on humans. The possible side effects produced by these sweeteners are: h-ERG blocking potential (glycyrrhizin, neohesperidin dihydrochalcone, advantame), eye and skin injuries (acesulfame K, cyclamates, saccharine), hepatotoxicity (saccharine), nephrotoxicity (steviol, glycyrrhizin), hypotension (advantame), mutagenicity and genotoxic carcinogenicity (acesulfame K, sucralose).
\end{abstract}

\section{Rezumat}

Prezentul studiu se concentrează pe predicția profilurilor farmacocinetice și a efectelor toxicologice ale principalilor îndulcitori folosiți pentru prevenirea și gestionarea diabetului zaharat: acesulfam K, advantam, aspartam, ciclamați, glicirizină, neotam, neohesperidină, steviol, sucraloză, tagatoză şi zaharină. Predicțiile obținute folosind mai multe instrumente computaționale au fost în general în concordanță și cu puținele date cunoscute cu privire la efectele acestor compuși asupra oamenilor. Posibilele efecte secundare produse de utilizarea îndulcitorilor investigați sunt: cardiotoxicitate prin inhibiţia canalului de potasiu în muşchiul cardiac (glicirizina, neohesperidina, advantamul), leziuni oculare și cutanate (acesulfam K, ciclamați, zaharina), hepatotoxicitate (zaharina), nefrotoxicitate (steviolul, glicirizina), hipotensiune (advantamul), mutagenicitate și carcinogenitate genotoxică (acesulfam K, sucraloza).

Keywords: intensive sweeteners, pharmacokinetics, toxicology

\section{Introduction}

The incidence and prevalence of type 2 diabetes is continuously rising, and weight loss is constantly recommended for both diabetes prevention and management. Intensive sweeteners (IS) provide an alternative to added sugars in food and drinks and, by limiting caloric intake, may facilitate the weight loss or maintenance. Consequently, these compounds are considered to provide patients with type 2 diabetes significant flexibility in their dietary preferences $[19$, 20, 30].

The present study focuses on the IS that are used as sugar substitutes and are recommended for people suffering of diabetes: aspartame, saccharin, sucralose, cyclamates, acesulfame potassium (acesulfame K), tagatose and steviol glucosides [25]. Intensive sweeteners are widely found in foods such as: baked goods, cereals, sweets, confectionary products, marmalades, canned food and fruit, bubble gum and as tabletop sweeteners (for coffee and others), etc. [8].

The consumption of IS is controversial, and the legislations of the countries and/or continents contradict each other when it comes to accepting or banning some of them (presented in Table I). Regulations and legislation concerning the use of food additives are under continuous re-examination and for some IS there are also restrictions concerning the allowed daily intake. All this information highlights the fact that the pharmacokinetics and biological effects of IS are not completely understood and they have not been fully investigated. Furthermore, most information revealing the effects of IS has been obtained through experiments performed on laboratory animals, usually rodents. These experiments imply considerable costs and there are also ethical concerns of using animals for testing purposes. Not at last, there are differences between rodents and humans in anatomy, physiology and metabolism and the extrapolation of results on humans can be problematic. There were proposed computational methods for toxicity testing such as to reduce the number of animal experiments and they become an integral part of technological platforms for assessing the toxicity of xenobiotics [14]. Taking into account the inconsistency of data regarding the health consequences of the IS intake as they have not 
been fully investigated, and the recognition of the computational methods for toxicity tests, the aim of this study is to perform a systematic review regarding the known human health hazards of the IS used in diabetes prevention and/or management and to further assess their side or toxicological effects on humans using a computational approach. The usefulness, challenges, and limitations of the use of computational models on obtaining more accurately outcomes for humans are also illustrated.

\section{Materials and Methods}

Within this study we have considered the IS widely used in the food and pharmaceutical industries that are also considered to be effective for diabetes management: acesulfame K, advantame, aspartame, cyclamic acid, sodium cyclamate, potassium cyclamate, calcium cyclamate, magnesium cyclamate, glycyrrhizin, neohesperidine dihydrochalcone, saccharin, steviol, sucralose and tagatose. For these sweeteners we made both a systematic review regarding their known toxicological effects on humans and obtained new information about their possible biological activities by using a computational approach.

In order to obtain up to date information regarding the effects of IS on humans we have followed the PRISMA recommendations [24, 40]. Consequently, for the investigated sweeteners we have collected the available information regarding their toxicological effects on humans by considering studies involving human subjects and not information obtained through experiments on laboratory animals. The following toxicological effects have been considered when acquiring information: various organs (lung, heart, skin, liver, kidney etc.) toxicity, mutagenicity, carcinogenicity, endocrine disruption potential and the causing of various diseases. We must underline that we did not take into account the metabolites of these sweeteners, being known that some of their metabolites are toxic [47]. Information has been extracted from the published articles in English (both research articles and review papers) that were found in scientific databases (Web of Science, ScienceDirect Freedom Collection, SringerLink Journal, SCOPUS) and PubChem database [21] and collections for all years until November 2020 were considered. Information acquired for every investigated sweetener has been synthetized and data are presented in Table I.

In order to predict the pharmacokinetics and biological effects of these molecules we have used few accurate computational tools that were extensively used for assessing the biological or side effects of various chemicals: synthetic steroids [34], phthalates [10], oligomers of chitin, chitosan [35] and their derivatives [18], cosmetic ingredients and pesticides [2, 16], low molecular weight oligomers of lactic acid [11] and of polydroxyalkanoates [36]. It highlights the applicability of these tools for predicting biological activity and toxicological endpoints for many classes of chemical compounds. These methods are shortly presented in the following.

For predicting absorption, distribution, metabolism, excretion and toxicity (ADMET) properties and the organ (eye, heart, liver) and genomic toxicity of investigated chemical compounds we have used admetSAR2.0 software [48]. It provides as output data the probability that a biological activity and a toxicological endpoint to be manifested (positive value of the probability) or not (negative value of the probability). More than 60 models with high predictive accuracy and defining various bioactivities are considered. The predictive accuracy of models used by this computational tool vary between $72.3 \%$ and $90.7 \%$ [48].

Pred-hERG4.2 computational tool [6] has been used for predicting the ability of the investigated compounds to inhibit the human ether-à-go-go related gene (hERG) $\mathrm{K}^{+}$channels. hERG $\mathrm{K}^{+}$channel inhibition may conduct to heart arrhythmia or even possibly death being one of the essential toxicological endpoints to be considered when evaluating the safety of xenobiotics. The predictions made using Pred-hERG computational tool have the accuracy of $89 \%$ [6].

Toxtree 3.1 is an open-source application that can be used to estimate toxicity by applying a decision tree approach, the accuracy of predictions being 70\% [31]. It incorporates several classification systems and rules that are used to predict for the chemical structures for analysis the skin and eye irritancy and corrosivity by physicochemical property limits and structural rules, skin sensitization potential, possible carcinogenic and mutagenicity potential by using a series of structural alerts and various QSAR models.

Prediction of Activity Spectra of Substances (PASS Online) is another web platform that can be used for predicting the biological activity, pharmacological effects, mechanisms of action, toxicity and adverse effects of investigated chemicals with a mean accuracy of prediction of about 95\% [31]. PASS Online calculates for every investigated compound, two probabilities in an independent manner: a probability to be active $(\mathrm{Pa})$ and a probability to be inactive (Pi) for a given biological action. When $\mathrm{Pa}>\mathrm{Pi}$ and $\mathrm{Pa}>$ 0.700 , there is a strong chance to find experimentally the predicted activity. Within this study the PASS Online platform has been used for predicting the side effects of the studied intensive sweeteners.

\section{Results and Discussion}

The information concerning the known toxicological effects on humans of the intensive sweeteners considered in this study are presented in Table I. This table also contains, for every considered sweetener, its structural formula, the acceptable daily intake (ADI) values 
established by Scientific Committee on Food (SCF) for Europe and the Joint FAO/WHO Expert Committee on Food Additives (JECFA) for international trade, the status of approval by the FDA (Food and Drug Administration) and EFSA (European Food Safety Authority), respectively. To the best of our knowledge, there is not information regarding the dangerous doses of the intensive sweeteners in the case of humans. The structural formulas have been obtained using ACD/ChemSketch utility [52] starting from the canonical or from the isomeric (when available) SMILE (Simplified Molecular Input Line Entry System) formula of the sweetener extracted from PubChem database [21].

Absorption and distribution profiles of the IS have been obtained using admetSAR2.0 software and are presented in Table II. Data in this table illustrate the probabilities that IS have (positive values) or have not (negative values) a specified pharmacokinetic property.

Table I

Intensive sweeteners considered in this study, their status of approval and known detrimental effects for humans

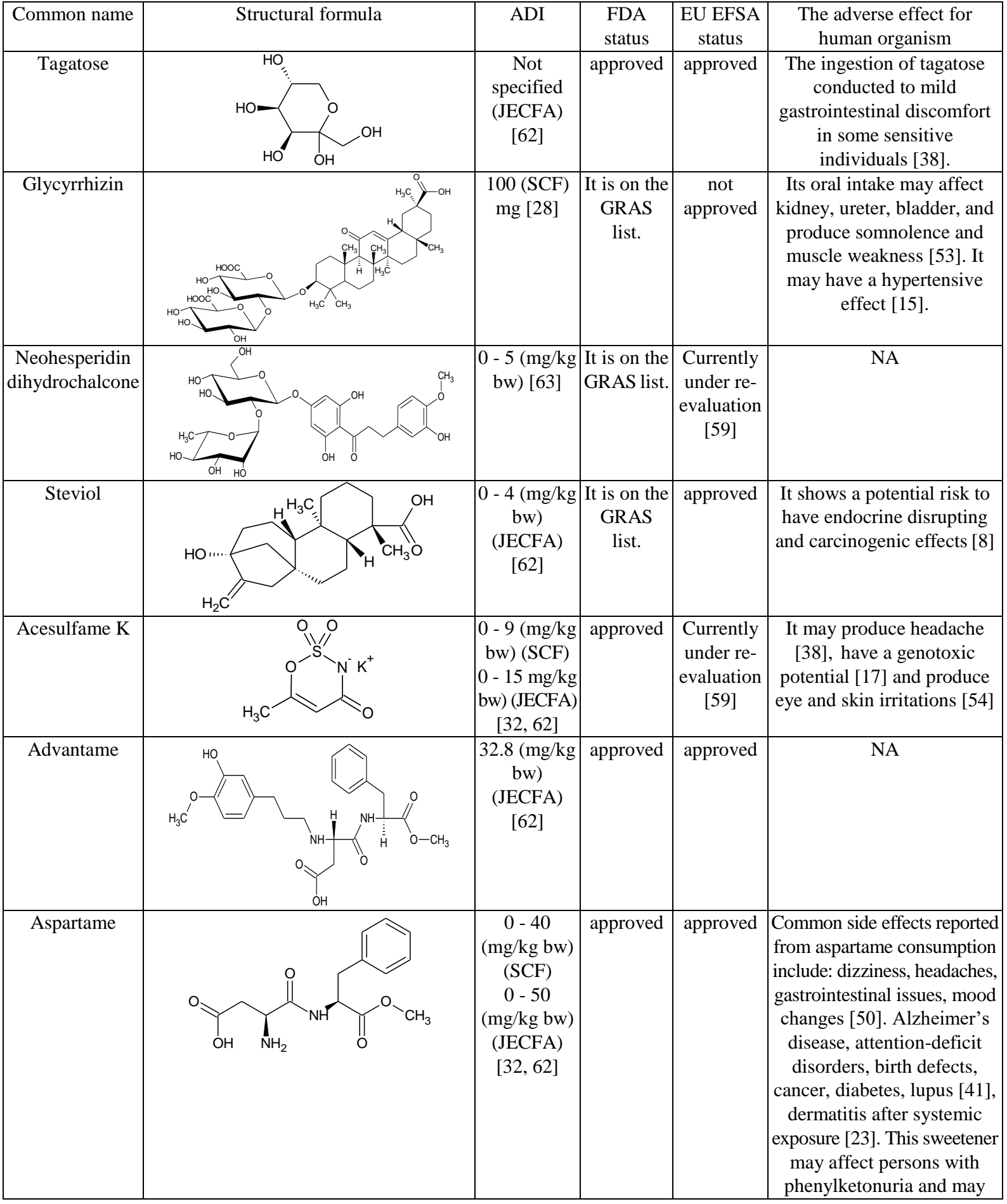


FARMACIA, 2021, Vol. 69, 6

\begin{tabular}{|c|c|c|c|c|c|}
\hline Common name & Structural formula & ADI & $\begin{array}{l}\text { FDA } \\
\text { status }\end{array}$ & $\begin{array}{c}\text { EU EFSA } \\
\text { status }\end{array}$ & $\begin{array}{c}\begin{array}{c}\text { The adverse effect for } \\
\text { human organism }\end{array} \\
\end{array}$ \\
\hline & & & & & $\begin{array}{l}\text { induce glucose intolerance by } \\
\text { altering gut microbiota [43]. }\end{array}$ \\
\hline Cyclamic acid & & \multirow{5}{*}{$\begin{array}{c}0-7 \text { (mg/kg } \\
\text { bw) (SCF) } \\
0-11 \\
(\mathrm{mg} / \mathrm{kg} \mathrm{bw}) \\
(\mathrm{JECFA}) \\
{[32,62]}\end{array}$} & $\begin{array}{l}\text { Not legal } \\
\text { in food }\end{array}$ & $\begin{array}{c}\text { Currently } \\
\text { under re- } \\
\text { evaluation } \\
\text { [59] }\end{array}$ & \multirow{5}{*}{$\begin{array}{l}\text { Cyclohexylsulfamic acid } \\
\text { produces skin and eye } \\
\text { irritations [55]. Exposure to } \\
\text { the sodium cyclamate may } \\
\text { conduct to irritations of the } \\
\text { skin, eyes, mucous membranes } \\
\text { and upper respiratory tract, } \\
\text { diarrhoea, photosensitization } \\
\text { and chromosomal changes [56]. } \\
\text { Potassium cyclamate produces } \\
\text { skin, eye and respiratory } \\
\text { irritations [57]. } \\
\text { Prolonged period of ingestion } \\
\text { of high amounts of cyclamates } \\
\text { developed vesical carcinoma } \\
\text { of bladder for } 3 \text { persons [4]. }\end{array}$} \\
\hline $\begin{array}{l}\text { Sodium } \\
\text { cyclamate }\end{array}$ & & & \begin{tabular}{|l|} 
Removed \\
from \\
GRAS list.
\end{tabular} & $\begin{array}{c}\text { Currently } \\
\text { under re- } \\
\text { evaluation } \\
\text { [59] }\end{array}$ & \\
\hline $\begin{array}{l}\text { Potassium } \\
\text { cyclamate }\end{array}$ & & & $\begin{array}{l}\begin{array}{l}\text { Removed } \\
\text { from } \\
\text { GRAS list. }\end{array} \\
\end{array}$ & $\begin{array}{l}\text { Data not } \\
\text { available. }\end{array}$ & \\
\hline $\begin{array}{l}\text { Calcium } \\
\text { cyclamate }\end{array}$ & & & \multirow{2}{*}{$\begin{array}{l}\text { Legal only } \\
\text { in products } \\
\text { complying } \\
\text { with drug } \\
\text { provisions } \\
\text { of the law. }\end{array}$} & \begin{tabular}{|c|} 
Currently \\
under re- \\
evaluation \\
{$[59]$} \\
\end{tabular} & \\
\hline $\begin{array}{c}\text { Magnesium } \\
\text { cyclamate }\end{array}$ & & & & $\begin{array}{c}\text { Data not } \\
\text { available. }\end{array}$ & \\
\hline Neotame & & $\begin{array}{c}0.3(\mathrm{mg} / \mathrm{kg} \\
\mathrm{bw}) \\
(\mathrm{JECFA}) \\
{[62]}\end{array}$ & approved & $\begin{array}{l}\text { Currently } \\
\text { under re- } \\
\text { evaluation } \\
{[60]}\end{array}$ & $\begin{array}{c}\text { It may produce headache and } \\
\text { illustrates hepatotoxicity at } \\
\text { high doses [50]. }\end{array}$ \\
\hline Saccharin & & $\begin{array}{c}0-5(\mathrm{mg} / \mathrm{kg} \\
\text { bw) (SCF } \\
\text { and JECFA) } \\
{[32,62]}\end{array}$ & approved & $\begin{array}{l}\text { Currently } \\
\text { under re- } \\
\text { evaluation } \\
\text { [59] }\end{array}$ & $\begin{array}{c}\text { It conducted to accumulation } \\
\text { of body fat in humans [46], } \\
\text { nausea, vomiting and diarrhoea } \\
\text { [50], hepatotoxicity [27], } \\
\text { anorexia, nausea, gastric } \\
\text { hyperacidity, coughing, chest } \\
\text { pain and irritation of the eyes, } \\
\text { nose and throat [58]. }\end{array}$ \\
\hline Sucralose & Cl' & $\begin{array}{c}0-5(\mathrm{mg} / \mathrm{kg} \\
\text { bw) (SCF } \\
\text { and JECFA) } \\
{[32,62]}\end{array}$ & approved & $\begin{array}{l}\text { Currently } \\
\text { under re- } \\
\text { evaluation } \\
{[57]}\end{array}$ & $\begin{array}{c}\text { Sucralose has been identified } \\
\text { as a causative agent in } \\
\text { generating migraine headaches } \\
\text { [29] and increasing incidence } \\
\text { of inflammatory bowel due } \\
\text { to its inhibiting effect on gut } \\
\text { bacteria and digestive protease } \\
\text { enzymes [33]. It may produce } \\
\text { diarrhoea [50]. }\end{array}$ \\
\hline
\end{tabular}

ADI - the acceptable daily intake; SCF - Scientific Committee on Food; JECFA - Joint FAO/WHO Expert Committee on Food Additives; GRAS - Generally Recognized as Safe

Table II

Absorption and distribution profiles of the investigated intensive sweeteners obtained using admetSAr2.0 software. The numerical values in this table represent the probabilities that investigated compounds have (positive values)

or have not (negative values) a certain biological action

\begin{tabular}{|l|c|c|c|c|c|}
\hline \multicolumn{1}{|c|}{ Name/ Pharmacokinetics properties } & HIA & PPB $(\%)$ & P-gpI & P-gpS & BBBP \\
\hline Tagatose & -0.961 & 0.413 & -0.980 & -0.905 & 0.879 \\
\hline Glycyrrhizin & 0.821 & 0.932 & -0.761 & -0.795 & -0.885 \\
\hline Neohesperidine dihydrochalcone & 0.697 & 0.800 & -0.684 & -0.509 & -0.515 \\
\hline Steviol & 0.968 & 0.811 & -0.835 & -0.811 & -0.537 \\
\hline Advantame & 0.771 & 0.962 & 0.647 & 0.734 & -0.377 \\
\hline
\end{tabular}


FARMACIA, 2021, Vol. 69, 6

\begin{tabular}{|l|c|c|c|c|c|}
\hline \multicolumn{1}{|c|}{ Name/ Pharmacokinetics properties } & HIA & PPB (\%) & P-gpI & P-gpS & BBBP \\
\hline Acesulfame K & 0.984 & 0.533 & -0.979 & -0.958 & 0.973 \\
\hline Aspartame & 0.719 & 0.679 & -0.927 & -0.766 & 0.943 \\
\hline Cyclamic acid & 0.737 & 0.423 & -0.984 & -0.978 & 0.965 \\
\hline Sodium cyclamate & -0.422 & 0.361 & -0.984 & -0.961 & 0.970 \\
\hline Potassium cyclamate & -0.422 & 0.443 & -0.984 & -0.961 & 0.972 \\
\hline Calcium cyclamate & -0.422 & 0.503 & -0.960 & -0.961 & 0.972 \\
\hline Magnesium cyclamate & -0.422 & 0.442 & -0.960 & -0.964 & 0.972 \\
\hline Neotame & 0.810 & 1.000 & -0.612 & 0.525 & 0.944 \\
\hline Saccharin & 0.993 & 0.874 & -0.991 & -0.951 & 0.970 \\
\hline Sucralose & -0.956 & 0.428 & -0.878 & -0.946 & 0.956 \\
\hline
\end{tabular}

HIA - human intestinal absorption; PPB - plasma proteins binding; P-gpI - inhibitor of the glycoprotein P;

P-gpS - substrate of the glycoprotein P; BBBP - blood-brain barrier penetration

Data presented in Table II illustrate that only tagatose, cyclamate salts and sucralose do not reveal good human intestinal absorption (HIA). Some of these outcomes are in good correlation with published information emphasizing that tagatose is mal-absorbed only 15 $20 \%$ of it being absorbed in the small intestine [7], absorption of cyclamates from the gut is incomplete [60], only $11-27 \%$ of ingested sucralose is absorbed from the gut, and acesulfame $\mathrm{K}$ and neotame are fast and almost completely absorbed [37].

All investigated sweeteners may interact with plasma proteins, but few of them reveal high probabilities for this interaction: glycyrrhizin, neohesperidine dihydrochalcone, steviol, advantame, neotame and saccharin. These results are also in good correlation with published data revealing the binding of some sweeteners to plasma proteins. Ali and Devrukhkar revealed in their study that aspartame and sucralose may cause glycation of plasma proteins [1]. Aspartame, acesulfame $\mathrm{K}$, sucralose and sodium cyclamate demonstrated a binding affinity to human serum albumin increasing its thermal stability [51], saccharin reversibly binds to plasma proteins being distributed via the blood to the body organs [45], an average of 82 $92 \%$ of advantame binds to plasma proteins and the binding of neotame to human plasma proteins in vitro ranged from $94 \%$ to $98 \%$.

Outcomes of admetSAR2.0 tools also reveal that none of the investigated sweeteners is considered as substrate (P-gpS) or inhibitor (P-gpI) of P-glycoprotein and they are in good correlation with the few published information on this subject. A study made by Sjöstedt et al. revealed that steviol, neohesperidine dihydrochalcone, acesulfame K, advantame, aspartame, cyclamates, saccharin, sucralose and neotame had no inhibitory potential against P-glycoprotein [42]. Wang et al. revealed that steviol glucuronide is not a P-gpS [49].

Excepting glycyrrhizin, neohesperidine dihydrochalcone, steviol and advantame, admetSARr2.0 predicts high probabilities of penetration of bloodbrain barrier for the other sweeteners. Many of the intensive sweeteners (aspartame, neotame, steviol) are metabolized to their metabolites in the gastrointestinal tract and consequently do not pass the blood brain barrier as intact sweeteners [39]. Cong et al. demonstrated that orally ingested acesulfame $\mathrm{K}$ is able to cross the mouse blood brain barrier and accumulate in brain tissue [9]. Another study revealed that aspartame was able to penetrate the blood-brain barrier and to produce disruption in neurotransmitters in rat brain [3]. It seems that this tool does not correctly predict the ability of the blood barrier permeation for all investigated IS. It underlines the limitations of the computational assessment of the biological effects of chemicals and the necessity to perform experimental studies to evaluate this property for the IS.

admetSAR2.0 computational facility also outcomes the probabilities that investigated sweeteners to be inhibitors of the transporter proteins/peptides: bile salt export pump (BSEP), organic cation transporter 2 (OCT2), multidrug and toxin extrusion 1 (MATE1), organic anion transporters (OATP) 1B1, 1B3 and 2B1, respectively (Figure 1). Figure 1 illustrates that all considered sweeteners reveal high probabilities to inhibit the organic anion transporters 1B1 and 1B3. In addition, BSEP may be inhibited by neohesperidine dihydrochalcone, glycyrrhizin, advantame and neotame, steviol and glycyrrhizin may also inhibit OCT2. These predictions are also in good agreement with the few published information revealing that steviol interacted with human organic anion transporters, particularly with those belonging to OATP1 and OATP3 families altering the renal drug clearance [43] and glycyrrhizin was found to interact with OATP1B1, OATP1B3, BSEP, OCT1, OCT3 and MATE1 [12].

Other predictions obtained using the admetSAR2.0 software concern the human organs toxicity of the investigated sweeteners and are revealed in Table III together with similar predictions obtained using Toxtree3.1 and Pred-hERG4.2 software, respectively. Several sweeteners are considered as producing eye irritations and corrosion, respectively skin irritations, but the predictions made by admetSAR2.0 and Toxtree3.1 are not always convergent. Data presented in Table I reveal that acesulfame potassium, cyclamates and saccharine are known to produce eye and skin injuries, confirming the predictions obtained using admetSAR2.0 computational tool. This tool also predicts that neohesperidine dihydrochalcone, acesulfame K, 
advantame, aspartame and saccharin may produce hepatotoxicity. Excepting the hepatotoxic effect of saccharine for one patient [27] and of aspartame that produced liver injury in mice [13], we were not able to find literature data regarding the hepatotoxicity of these sweeteners. Acesulfame $\mathrm{K}$ and sucralose are considered as producing mutagenic effects and presenting genotoxic carcinogenicity. These predictions are in good concordance with published studies revealing the genotoxic effect of acesulfame K [17] and it was reported that high doses of saccharin and sucralose conducted to carcinoma and mutagenesis in rats [22]. The outcomes of admetSAR2.0 software also reveal that neohesperidine dihydrochalcone and advantame illustrate a potential to inhibit $\mathrm{hERG} \mathrm{K}^{+}$cannel and to produce cardiotoxicity. The two sweeteners, added to glycyrrhizin, are also indicated as potential h-ERG inhibitors by Pred-hERG4.2 software. Pred-hERG computational tool outcomes, for every investigated compound, the map illustrating the predicted contribution of chemical fragments to the hERG blockage.

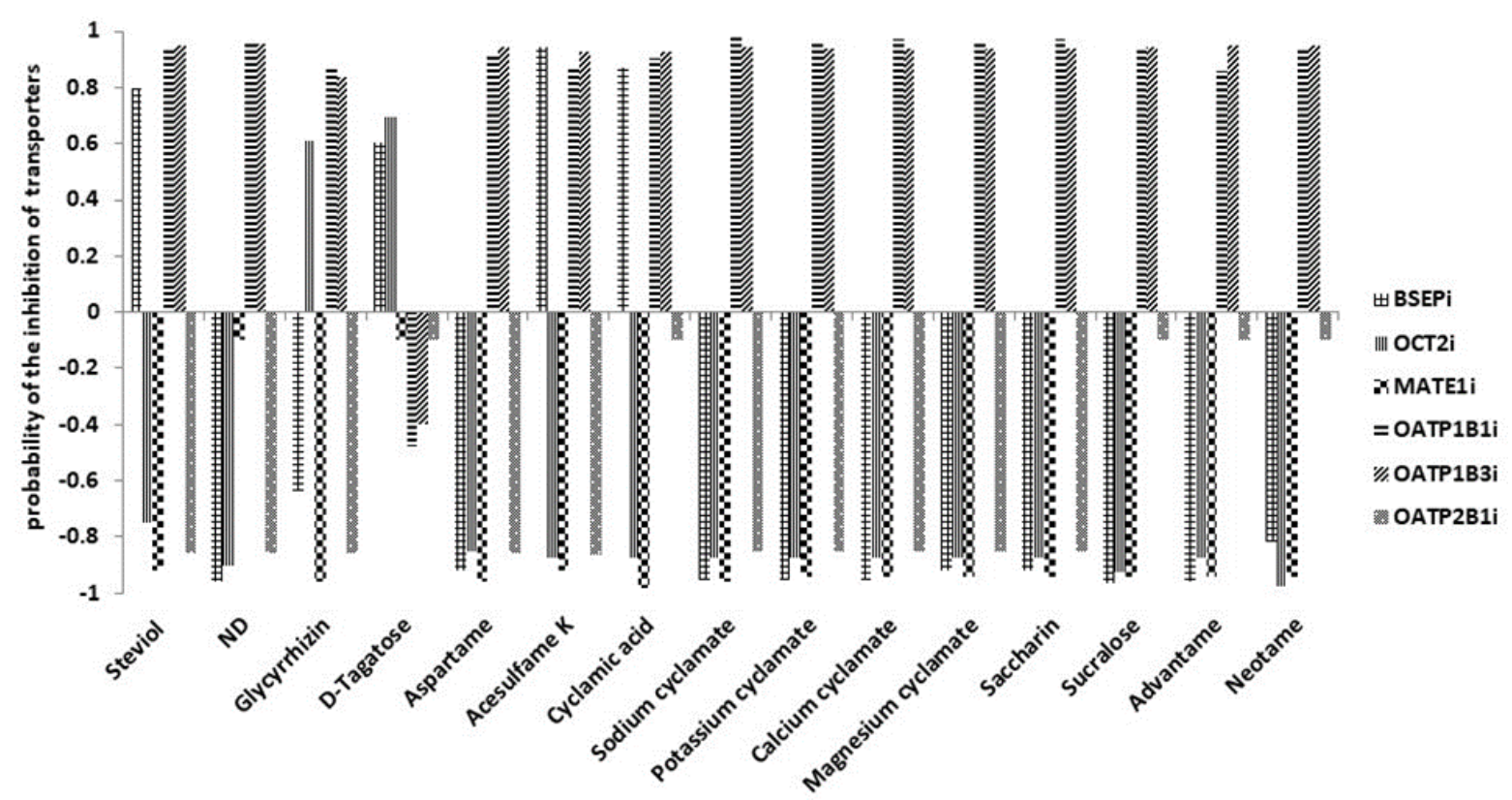

Figure 1.

admetSAR2.0 outcomes regarding the probabilities that investigated sweeteners to be inhibitors of the transporter proteins/peptides

BSEP - bile salt export pump; OCT2 - organic cation transporter 2; MATE1 - multidrug and toxin extrusion 1;

OATP - organic anion transporters 1B1, 1B3 and 2B1, respectively; ND - neohesperidine dihydrochalcone

Table III

Predictions obtained using admetSAR2.0, Toxtree3.1 and Pred-hERG4.2 concerning the toxicological endpoints of the investigated sweeteners. Cells in grey illustrate toxicity and those in light grey illustrate unknown effects.

\begin{tabular}{|c|c|c|c|c|c|c|c|c|c|c|c|}
\hline \multirow{3}{*}{$\begin{array}{l}\text { Common name } \\
\text { of sweetener/ } \\
\text { Toxicological } \\
\text { endpoint/Tool }\end{array}$} & \multirow{3}{*}{\multicolumn{2}{|c|}{\begin{tabular}{|c|c|}
$\begin{array}{c}\text { Eye } \\
\text { injury }\end{array}$ & $\begin{array}{c}\text { Eye } \\
\text { corrosion }\end{array}$ \\
\multicolumn{2}{|c|}{ admetSAR2.0 }
\end{tabular}}} & \multirow{3}{*}{\begin{tabular}{|c|}
$\begin{array}{c}\text { Eye } \\
\text { irritation } \\
\text { and } \\
\text { corrosion }\end{array}$ \\
Toxtree \\
3.1 \\
\end{tabular}} & \multirow{3}{*}{\begin{tabular}{|c|}
$\begin{array}{c}\text { Skin } \\
\text { irritation } \\
\text { and } \\
\text { corrosion }\end{array}$ \\
Toxtree \\
3.1 \\
\end{tabular}} & \multirow{3}{*}{$\begin{array}{c}\text { HEPT }^{\dagger} \\
\\
\text { admet } \\
\text { SAR2.0 }\end{array}$} & \multicolumn{2}{|c|}{ Ames mutagenesis } & \multicolumn{2}{|c|}{ Carcinogenesis } & \multicolumn{2}{|c|}{ Cardiotoxicity } \\
\hline & & & & & & & & & & & \\
\hline & & & & & & $\begin{array}{l}\text { admet } \\
\text { SAR2.0 }\end{array}$ & $\begin{array}{c}\text { Toxtree } \\
3.1\end{array}$ & $\begin{array}{l}\text { admet } \\
\text { SAR2.0 }\end{array}$ & Toxtree 3.1 & $\begin{array}{l}\text { admet } \\
\text { SAR2.0 }\end{array}$ & $\begin{array}{c}\text { Pred- } \\
\text { hERG4.2 }\end{array}$ \\
\hline D-Tagatose & -0.941 & -0.987 & No & No & -0.875 & -0.600 & No & -0.985 & No & -0.629 & $\begin{array}{c}\mathrm{NO} \\
(70 \%)\end{array}$ \\
\hline Glycyrrhizin & -0.908 & -0.990 & No & No & -0.525 & -0.670 & No & -0.985 & No & -0.454 & $\begin{array}{c}\text { YES } \\
(60 \%)\end{array}$ \\
\hline $\begin{array}{l}\text { Neohesperidine } \\
\text { dihydrochalcone }\end{array}$ & -0.921 & -0.989 & No & No & 0.575 & -0.850 & No & -0.914 & No & 0.729 & $\begin{array}{l}\text { YES } \\
(60 \%)\end{array}$ \\
\hline Steviol & -0.725 & -0.994 & No & No & -0.550 & -0.910 & No & -0.842 & No & -0.500 & $\begin{array}{c}\mathrm{NO} \\
(70 \%)\end{array}$ \\
\hline Acesulfame K & 0.915 & -0.938 & No & No & 0.550 & -0.790 & Yes & -0.844 & $\begin{array}{l}\text { Structural } \\
\text { alert for } \\
\text { genotoxic } \\
\text { carcino- } \\
\text { genicity }\end{array}$ & -0.808 & $\begin{array}{c}\mathrm{NO} \\
(60 \%)\end{array}$ \\
\hline
\end{tabular}


FARMACIA, 2021, Vol. 69, 6

\begin{tabular}{|c|c|c|c|c|c|c|c|c|c|c|c|}
\hline \multirow{3}{*}{$\begin{array}{l}\text { Common name } \\
\text { of sweetener/ } \\
\text { Toxicological } \\
\text { endpoint/Tool }\end{array}$} & \multirow{3}{*}{\multicolumn{2}{|c|}{\begin{tabular}{|c|c|}
$\begin{array}{c}\text { Eye } \\
\text { injury }\end{array}$ & $\begin{array}{c}\text { Eye } \\
\text { corrosion }\end{array}$ \\
\multicolumn{2}{|c|}{ admetSAR2.0 }
\end{tabular}}} & \multirow{3}{*}{\begin{tabular}{|c|}
$\begin{array}{c}\text { Eye } \\
\text { irritation } \\
\text { and } \\
\text { corrosion }\end{array}$ \\
Toxtree \\
3.1 \\
\end{tabular}} & \multirow{3}{*}{\begin{tabular}{|c|}
$\begin{array}{c}\text { Skin } \\
\text { irritation } \\
\text { and } \\
\text { corrosion }\end{array}$ \\
Toxtree \\
3.1 \\
\end{tabular}} & \multirow{3}{*}{$\begin{array}{c}\text { HEPT }^{\dagger} \\
\\
\text { admet } \\
\text { SAR2.0 }\end{array}$} & \multicolumn{2}{|c|}{ Ames mutagenesis } & \multicolumn{2}{|c|}{ Carcinogenesis } & \multicolumn{2}{|c|}{ Cardiotoxicity } \\
\hline & & & & & & & & & Toxt & & \\
\hline & & & & & & SAR2.0 & 3.1 & SAR2.0 & & SAR2.0 & hERG4.2 \\
\hline Advantame & -0.981 & -0.992 & & Yes & 0.725 & -0.740 & No & -0.792 & No & 0.817 & $\begin{array}{l}\text { YES } \\
(50 \%,\end{array}$ \\
\hline Aspartame & -0.997 & -0.994 & No & No & 0.575 & -0.720 & No & -0.728 & No & -0.524 & $\begin{array}{c}\mathrm{NO} \\
(70 \%)\end{array}$ \\
\hline Cyclamic acid & 0.921 & -0.839 & unknown & Yes & -0.675 & -0.810 & No & -0.642 & No & -0.563 & $\begin{array}{c}\mathrm{NO} \\
(80 \%)\end{array}$ \\
\hline $\begin{array}{l}\text { Sodium } \\
\text { cyclamate }\end{array}$ & 0.921 & -0.919 & unknown & unknown & -0.675 & -0.850 & No & -0.657 & No & -0.563 & $\begin{array}{c}\mathrm{NO} \\
(70 \%)\end{array}$ \\
\hline $\begin{array}{l}\text { Potassium } \\
\text { cyclamate }\end{array}$ & 0.921 & -0.919 & unknown & unknown & -0.675 & -0.840 & No & -0.657 & No & -0.563 & $\begin{array}{c}\mathrm{NO} \\
(70 \%)\end{array}$ \\
\hline $\begin{array}{l}\text { Calcium } \\
\text { cyclamate }\end{array}$ & 0.706 & -0.947 & No & No & -0.725 & -0.850 & No & -0.657 & No & -0.602 & $\begin{array}{c}\mathrm{NO} \\
(70 \%)\end{array}$ \\
\hline $\begin{array}{l}\text { Magnesium } \\
\text { cyclamate }\end{array}$ & 0.706 & -0.947 & unknown & unknown & -0.725 & -0.840 & No & -0.657 & No & -0.602 & $\begin{array}{c}\mathrm{NO} \\
(70 \%)\end{array}$ \\
\hline Neotame & -0.981 & -0.989 & Yes & Yes & -0.525 & -0.780 & No & -0.557 & No & -0.869 & $\begin{array}{c}\mathrm{NO} \\
(60 \%)\end{array}$ \\
\hline Saccharin & 0.955 & -0.955 & No & No & 0.675 & -0.900 & No & -0.637 & No & -0.500 & $\begin{array}{l}\text { NO } \\
(60 \%)\end{array}$ \\
\hline Sucralose & -0.990 & -0.985 & Yes & Yes & 0.775 & 0.540 & Yes & -0.857 & $\begin{array}{l}\text { Structural } \\
\text { alert for } \\
\text { genotoxic } \\
\text { carcino- } \\
\text { genicity }\end{array}$ & -0.629 & $\begin{array}{c}\mathrm{NO} \\
(70 \%)\end{array}$ \\
\hline
\end{tabular}

${ }^{\dagger}$ HEPT - hepatotoxicity

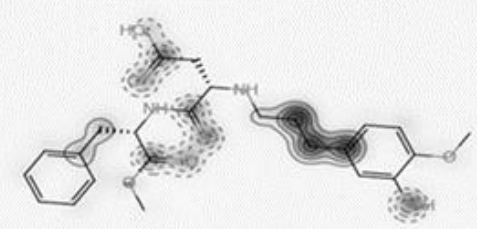

a

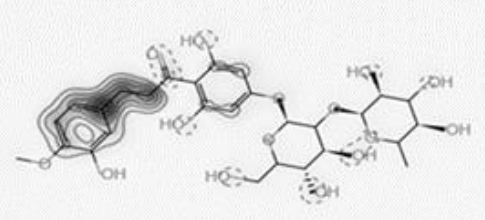

b

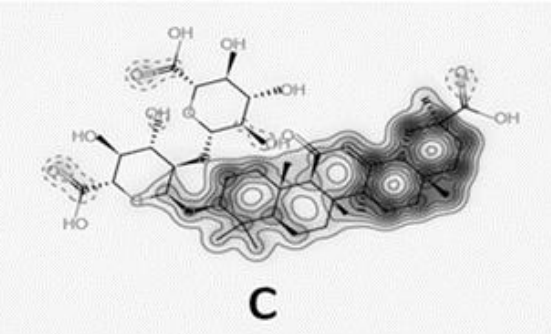

Figure 2.

The maps emphasizing contributions of chemical fragments toward hERG blockage for the sweeteners revealing hERG blockage potential: advantame (a), neohesperidine dihydrochalcone (b) and glycyrrhizin (c). Fragments with continuous contours denote contribution towards blockage of hERG, fragments with dashed contours contribute to decrease of hERG blockage.

The maps emphasizing contributions of chemical fragments for glycyrrhizin, neohesperidine dihydrochalcone and advantame (compounds illustrating hERG blocking potential) are presented in Figure 2 and illustrate that every compound possesses both fragments contributing to hERG blockage potential (continuous line contours in Figure 2) and fragments diminishing this potential (dashed lines contours in Figure 2).

Glycyrrhizin reveals the highest amount of fragments contributing to the h-ERG blockage potential. Advantame is considered as a potential hERG inhibitor by both computational tools. PASS online computational facility also predicts that advantame may produce 
hypotension. We were not able to identify literature data confirming or infirming the hERG blockage potential in humans of the IS, but this study underlines that the hERG blockage potential of advantame, glycyrrhizin and neohesperidine dihydrochalcone should be considered for further investigations.

The outcomes of PASS online tool reveal few side effects of investigated sweeteners (in parentheses are presented the probabilities of these sweeteners to be active toward a side effect): tagatose may produce hyperuricemia (0.788), steviol has a nephrotoxic effect (0.850), saccharin may lead to neutrophilic dermatosis (0.823), sucralose may produce drowsiness (0.909), advantame may produce hypotension $(0.887)$, neotame (0.876) and aspartame (0.843) may conduct to shivering and cyclamic acid may have a weight loss effect. Glycyrrhizin reveals multiple side effects: muscle weakness (0.982), general weakness (0.980), behavioural disturbance (0.948) and nephrotoxicity (0.938). Some of these predictions are in good agreement with published information (Table I). Charged compounds (acesulfame K and cyclamates) cannot be processed by this computational tool and there are not predictions regarding their side effects.

Many publications reveal the applicability of computational modelling for predicting the biological activities and ADMET properties of chemical, agrochemical, pharmaceutical, cosmetics and food industries by providing significant guidance in planning experiments. Computational prediction of the biological effects of chemical compounds is usually based on the supposition that structurally similar compounds display similar biological effects, but it is also possible that small structural changes lead to distinct biological activity, this being a major factor limiting the predictability of these models [26]. Such limitations can be overcome by using several models [5] and we have used several computational tools that are based on different models for predicting the same biological activity of the IS, the outcomes being compared. Another limitation of the computational predictions, that is also common to the in vitro experimental assessments, is expressed by the fact that the evaluation of responses at the level of the whole organism implies understanding of the complex biological processes. Taking into account both the opportunities and limitations of these methods, the obtained predictions should be used to guide further experimental evaluation of the safety use of these chemical compounds.

\section{Conclusions}

Within this study we have used several computational tools in order to obtain predictions concerning ADMET properties and toxicological endpoints of the most used intensive sweeteners for preventing and/or management of diabetes. Usually, the predictions obtained by various tools are in good agreement each other and some of the obtained predictions are also in good agreement with the few literature data registering the toxic effects of intensive sweeteners on humans, as presented in this article.

Glycyrrhizin, neohesperidine dihydrochalcone and advantame are the sweeteners illustrating hERG blocking potential, acesulfame K, cyclamates and saccharine are considered to produce eye and skin injuries, and neohesperidine dihydrochalcone, acesulfame $\mathrm{K}$, advantame, aspartame and saccharin may produce hepatotoxicity. Other identified toxicological effects were the mutagenic effects and genotoxic carcinogenicity for acesulfame $\mathrm{K}$ and sucralose.

\section{Conflict of interest}

The authors declare no conflict of interest.

\section{References}

1. Ali A, Devrukhkar J, In vitro study on glycation of plasma proteins with artificial sweeteners. Acta Biologica Szegediensis, 2016; 60(1): 65-70.

2. Alves VM, Muratov EN, Zakharov A, Muratov NN, Andrade $\mathrm{CH}$, Tropsha A, Chemical toxicity prediction for major classes of industrial chemicals: Is it possible to develop universal models covering cosmetics, drugs, and pesticides?. Food Chem Toxicol., 2018; 112: 526-534.

3. Baothman OAS, Moselhy SS, Al-Shehri SH, ALMalki AL, Impact of aspartame consumption on neurotransmitters in rat brain. Afr $J$ Tradit Complem Altern Medicines, 2017; 14(5): 89-95.

4. Barkin M, Comisarow RH, Taranger LA, Canada A, Three Cases of Human Bladder Cancer Following High Dose Cyclamate Ingestion. J Urol., 1977; 118(2): 258-259.

5. Benfenatia E, Chaudhryb Q, Ginic G, Dorne JL, Integrating in silico models and read-across methods for predicting toxicity of chemicals: A step-wise strategy. Environ Int., 2019; 131: 105060: 1-15.

6. Braga RC, Alves VM, Silva MFB, Muratov E, Fourches D, Lião LM, Tropsha A, Andrade CH, Pred-hERG: A novel web-accessible computational tool for predicting cardiac toxicity. Mol Inform., 2015; 34(10): 698-701.

7. Buemann B, Toubro S, Raben A, Blundell J, Astrup A, The acute effect of D-tagatose on food intake in human subjects. Br J Nutr., 2000; 84(2): 227-231.

8. Carocho M, Morales P, Ferreira ICFR, Sweeteners as food additives in the XXI century: A review of what is known, and what is to come. Food Chem Toxicol., 2017; 107(Pt A): 302-317.

9. Cong W, Wang R, Cai H, Daimon CM, ScheibyeKnudsen M, Bohr VA, Turkin R, Wood $3^{\text {rd }}$ WH, Becker KG, Moaddel R, Maudsley S, Martin B, Long-term artificial sweetener acesulfame potassium treatment alters neurometabolic functions in C57BL/ 6J mice. PLoS One, 2013; 8: e70257: 1-18.

10. Craciun D, Dascalu D, Isvoran A, Computational assessment of the ADME-Tox profiles and harmful effects of the most common used phthalates on the 
human health. Studia Universitatis Babeș-Bolyai Chemia., 2019; 64: 71-92.

11. Dascalu D, Roman D, Filip M, Ciorsac A, Ostafe V, Isvoran A, Solubility and ADMET profiles of short oligomers of lactic acid. ADMET \& DMPK, 2020; 8(4): 425-436.

12. Dong J, Olaleye OE, Jiang R, Li J, Lu C, Du F, Xu F, Yang J, Wang F, Jia W, Li C, Glycyrrhizin has a high likelihood to be a victim of drug-drug interactions mediated by hepatic organic anion-transporting polypeptide 1B1/1B3. Br J Pharmacol., 2018; 175: 3486-3503.

13. Finamor I, Pérez S, Bressan CA, Brenner CE, RiusPérez S, Brittes PC, Cheiran G, Rocha MI, da Veiga M, Sastre J, Pavanato MA, Chronic aspartame intake causes changes in the trans-sulphuration pathway, glutathione depletion and liver damage in mice. Redox Biol., 2017; 11: 701-707.

14. Gleeson MP, Modi S, Bender A, Robinson RLM, Kirchmair J, Promkatkaew M, Hannongbua S, Glen $\mathrm{RC}$, The challenges involved in modeling toxicity data in silico: A review. Curr Pharm Des., 2012; 18(8): 1266-1291.

15. Graebin CS, The Pharmacological Activities of Glycyrrhizinic Acid ("Glycyrrhizin") and Glycyrrhetinic Acid. Sweeteners, 2018; 31: 245-261.

16. Gridan IM, Ciorsac AA, Isvoran A, Prediction of ADME-Tox properties and toxicological endpoints of triazole fungicides used for cereals protection. ADMET\&DMPK, 2019; 7(3): 161-173.

17. Harpaz D, Yeo LP, Cecchini F, Koon THP, Measuring Artificial Sweeteners Toxicity Using a Bioluminescent Bacterial Panel. Molecules. 2018; 23(10): 2454: 1-20.

18. Isvoran $\mathrm{A}$, Ciorsac $\mathrm{A}$, Ostafe $\mathrm{V}, \mathrm{ADME}-\mathrm{Tox}$ profiling of some low molecular weight water soluble chitosan derivatives. ADMET\&DMPK, 2017; 5(3): 192-200.

19. Iosif L, Lixandru D, Gaman L, Ilie M, Smeu B, Ştefan Ds, Petcu L, Picu A, Constantin A, Ionescu-Tîrgovişte C, Guja C, Copăescu C, Stoian I. Oxidative stress profile and type 2 diabetes remission at 6 months after sleeve gastrectomy versus conservatory treatment. Farmacia, 2019, 67(1): 99-105.

20. Johnston CA, Stevens B, Foreyt JP, The Role of Low-calorie Sweeteners in Diabetes. Eur Endocrinol., 2013; 9(2): 96-98.

21. Kim S, Chen J, Cheng T, Gindulyte A, He J, He S, Li Q, Shoemaker BA, Thiessen PA, Yu B, Zaslavsky L, Zhang J, Bolton EE, PubChem 2019 update: improved access to chemical data. Nucleic Acids Res., 2019; 47(D1): D1102-D1109.

22. Kroger M, Meister K, Kava R. Low-calorie Sweeteners and Other Sugar Substitutes: A Review of the Safety Issues. Comp Rev Food Sci Food Safety, 2006; 5(2): 35-47.

23. Kulczycki A, Aspartame-induced urticaria. Ann Intern Med., 1986; 104(2): 207-208.

24. Moher D, Shamseer L, Clarke M, Ghersi D, Liberati A, Petticrew M, Shekelle P, Stewart LA, Preferred Reporting Items for Systematic Review and MetaAnalysis Protocols (PRISMA-P) 2015 statement. Syst Rev., 2015; 4(1): 1: 1-9.

25. Mooradian AD, Smith M, Tokuda M, The role of artificial and natural sweeteners in reducing the consumption of table sugar: A narrative review. Clin Nutr ESPEN., 2017; 18: 1-8.

26. Muratov EN, Bajorath J, Sheridan RP, Tetko IV, Filimonov D, Poroikov VL, Oprea TI, Baskin II, Varnek A, Roitberg A, Isayev O, Curtalolo S, Fourches D, Cohen Y, Aspuru-Guzik A, Winkler DA, Agrafiotis D, Cherkasov A, Tropsha A, QSAR without borders. Chem Soc Rev., 2020; 49(11): 3525-3564.

27. Negro E, Mondardini A, Palmas E, Hepatotoxicity of saccharin. N Engl J Med., 1994; 331(2): 134-135.

28. Omar HR, Komarova I, El-Ghonemi M, Fathy A, Rashad R, Abdelmalak HD, Yerramadha MR, Ali Y, Helal E, Camporesi EM, Licorice abuse: time to send a warning message. Ther Adv Endocrinol Metab., 2012; 3(4): 125-138.

29. Patel RM, Sarma R, Grimsley E, Popular sweetener sucralose as a migraine trigger. Headache, 2006; 46(8): 1303-1304

30. Patlewicz G, Jeliazkova N, Safford R.J, Worth AP, An evaluation of the implementation of the Cramer classification scheme in the Toxtree software. SAR QSAR Environ Res., 2008; 19(5-6): 495-524.

31. Poroikov VD, Filimonov LA, Gloriozova T, PASS: Identification of probable targets and mechanisms of toxicity. SAR QSAR Environ Res., 2007; 18(1-2): 101-110.

32. Qin X, What made Canada become a country with the highest incidence of inflammatory bowel disease: Could sucralose be the culprit?. Can J Gastroenterol., 2011; 25(9): 511.

33. Renwick AG, The intake of intense sweeteners - an update review. Food Addit Contam., 2006; 23(4): 327-338.

34. Roman M, Roman DL, Ostafe V, Computational assessment of pharmacokinetics and biological effects of some anabolic and androgenic steroids. Pharm Res., 2018; 35(2): 41: 1-25.

35. Roman DL, Roman M, Som C, Schmutz M, Hernandez E, Wick P, Casalini T, Perale G, Ostafe V, Isvoran A, Computational Assessment of the Pharmacological Profiles of Degradation Products of Chitosan. Front Bioeng Biotechnol., 2019; 7: 214: 1-16.

36. Roman D, Isvoran A, Filip M, Ostafe V, Zinn M, In silico Assessment of Pharmacological Profile of Low Molecular Weight Oligo-Hydroxyalkanoates. Front Bioeng Biotechnol., 2020; 8: 584010: 1-12.

37. Ruiz-Ojeda FJ, Plaza-Díaz J, Sáez-Lara MJ, Gli A, Effects of Sweeteners on the Gut Microbiota: A Review of Experimental Studies and Clinical Trials. Adv Nutr., 2019; 10(suppl_1): S31-S48.

38. Saulo AA, Sugars and Sweeteners in Foods. Food Safety Technol., 2005; 16: 1-7.

39. Schiffman SS, Rationale for Further Medical and Health Research on High-Potency Sweeteners. Chem Senses, 2012; 37(8): 671-679.

40. Shamseer L, Moher D, Clarke M, Ghersi D, Liberati A, Petticrew M, Shekelle P, Stewart LA, PRISMA-P Group, Preferred Reporting Items for Systematic Review and Meta-Analysis Protocols (PRISMA-P) 2015: elaboration and explanation. BMJ., 2015; 349: g7647: 1-25.

41. Shankar P, Ahuja S, Sriram K, Non-nutritive sweeteners: Review and update. Nutrition, 2013; 29(11-12): 1293-1299. 
42. Sjöstedt N, Deng F, Oskari R, Tepponen T, Kidron $\mathrm{H}$, Interaction of Food Additives with Intestinal Efflux Transporters. Mol Pharm., 2017; 14(11): 3824-3833.

43. Srimaroeng C, Jutabha P, Pritchard JB, Endou H, Chatsudthipong V, Interactions of stevioside and steviol with renal organic anion transporters in $S_{2}$ cells and mouse renal cortical slices. Pharm Res., 2005; 22(6): 858-866.

44. Suez J, Korem T, Zeevil D, Zilberman-Schapira G, Thaiss CA, Maza O, Israeli D, Zmora N, Gilad S, Weinberger A, Kuperman Y, Harmelin A, KolodkinGal I, Shapiro H, Halpern Z, Segal E, Elinav E, Artificial sweeteners induce glucose intolerance by altering the gut microbiota. Nature, 2014; 514(7521): 181-186.

45. Sweatman TW, Renwick AG, The tissue distribution and pharmacokinetics of saccharin in the rat. Toxicol Appl Pharmacol., 1980; 55(1): 18-31.

46. Swithers SE, Martin AA, Davidson TL, High intensity sweeteners and energy balance. Physiol Behav., 2010; 100(1): 55-62.

47. Takayama S, Renwick AG, Johansson SL, Thorgeirsson UP, Tsutsumi M, Dalgard DW, Sieber SM, Longterm toxicity and carcinogenicity study of cyclamate in nonhuman primates. Toxicol Sci., 2000; 53(1): 3339.

48. Yang H, Lou C, Sun L, Li J, Cai Y, Wang Z, Li W, Liu G, Tang Y, admetSAR 2.0: web-service for prediction and optimization of chemical ADMET properties. Bioinformatics, 2019; 35(6): 1067-1069.
49. Wang M, Qi H, Li J, Xu Y, Zhang H, Transmembrane transport of steviol glucuronide and its potential interaction with selected drugs and natural compounds. Food Chem Toxicol., 2015; 86: 217-224.

50. Withehouse CR, Boullata J, McCauley LA, The potential toxicity of artificial sweeteners. AAOHN J., 2008; 56: 251-259.

51. Zhang H, Sun S, Wang Y, Fei Z, Cao J, Binding mechanism of five typical sweeteners with bovine serum albumin. Spectrochim Acta A Mol Biomol Spectrosc., 2018; 205: 40-47.

52. https://chemicalize.com.

53. https://pubchem.ncbi.nlm.nih.gov/compound/14982.

54. www.medisca.com/NDC_SPECS/MUS/2590/MSD S/2590.pdf.

55. https://pubchem.ncbi.nlm.nih.gov/compound/7533

56. https://pubchem.ncbi.nlm.nih.gov/compound/23665 706.

57. https://pubchem.ncbi.nlm.nih.gov/compound/8752 .

58. https://pubchem.ncbi.nlm.nih.gov/compound/5143.

59. www.efsa.europa.eu/sites/default/files/consultation/ callsfordata/190513-cfd.pdf.

60. https://ec.europa.eu/food/sites/food/files/safety/doc s/sci-com_scf_out53_en.pdf.

61. www.inchem.org/documents/jecfa/jecmono/v52je0 8.html.

62. www.fda.gov/food/food-additives-petitions/highintensity-sweeteners.

63. www.fda.gov/media/137761/download. 